\title{
Study of Eco-Touristic Services and Forest Rehabilitation Activities in the Context of Pandemic Covid-19 and Other Affecting Factors by the Example of Hrazdan Forest Farm
}

\author{
E.A. Zakaryan, M.H. Galstyan, K.Sh. Sargsyan, E.F. Gevorgyan \\ Armenian National Agrarian University \\ elmira.zaqaryan.98@mail.ru,galstyan.merujan@mail.ru, karinesargsyan.1970@mail.ru, emil.gevorg.gevorgyan@gmail.com
}

\section{A R T I C L E I N F O}

\section{Keywords:}

eco-touristic services,

forest rehabilitation,

surveys and evaluation,

pandemic and war,

consequences

\begin{abstract}
A B S T RA C T
The study results have disclosed that in 2020 , due to pandemic and war, only recreation and eco-touristic services estimated as $10 \mathrm{mln} 755$ thousand (30.6\% of the total) AMD were rendered against those of total $35 \mathrm{mln} 145$ thousand AMD available in Tsaghkadzor city, while the forest rehabilitation activities were underperformed by 3 hectare land area or by $33.3 \%$; besides, illegal logging increased by 1.8 and 2.2 ha respectively as compared to the previous two years.

So, forest ecosystem-based recreation and eco-touristic services should be integrated in the overall economic system, while at least $30 \%$ of profit should be allocated for the conservation of forest landscapes.
\end{abstract}

\section{Introduction}

Forest and agroecosystem services are structural and system-based functions which directly or indirectly contribute to the welfare of population. Therefore, human life activity and public welfare are mainly related to both natural capital and current geo-ecosystems, which provide a base for ongoing ecosystem services from nature to social medium (Avetisyan, 2017, Concept of Creating Innovative Financial and Economic Mechanisms in the Field of Nature Protection, 2013, Galstyan and Mkrtchyan, 2013). Besides, diverse ecosystem services are vital tools for decision-making, efficient management and legislation improvement measures in the branch of environmental protection at global, regional and local levels. Along with biodiversity, ecological balance, genetic resource, species habitat and food provision, the forest ecosystem also provides intangible, nonmaterial and physiological amenities, which people receive either from directly those systems or as a result of contacting with them (Gevorgyan, 2014, Global Carbon Project Report - Earth Syst. Sci. Data, 2015).

Thus, any research, aimed at the evaluation and promotion of forest geo-ecosystem services and forest rehabilitation activities, particularly in the context of 
pandemic and Artsakh war, is actual and stems from the requirements of the strategy developed for improving forest geo-ecosystems of the Republic of Armenia (RA).

\section{Materials and methods}

For the assessment of ecosystem services, a wellknown research work titled as "The Economics of Ecosystems and Biodiversity (TEEB)" (Gevorgyan, 2014) has served as a background. TEEB was approved within the framework of joint activities between German and European Committee, in 2007. In this case study an attempt was made to assess some services of forest geo-ecosystem in the Hrazdan province of the Kotayk region, which could promote the eco-tourism development in the central regions of the RA.

The studies were conducted based on the analyses and estimations of the opportunities for recreation and eco-touristic services available in the Hrazdan forest enterprise. The mentioned services rendered by the Hrazdan forest geo-systems have been assessed for the first time according to the methodology developed by A.A. Yermakova (Yermakova, 2009).

The data on the Hrazdan forest geo-systems (forest rehabilitation, care, etc.) have been retrieved from the branch of Hrazdan Forest Farm and the indices for the soils' qualitative and quantitative properties were found in the atlas of the RA soils (Atlas of Soils of the RA, 1990). During the investigations the current publications (http://www.mnp.am/, http://kotayk.mtad.am/kotayk/, http://forestcommittee.am) about the services of forest and agroecosystems in the Kotayk region have been used.

In the current research work the estimation of demographic rate per recreation resources for the Tsaghkadzor forest district has been conducted and presented as a reference example. The recreation capacity of natural complexes is interpreted as the maximum value of permissible burden for the territory of those complexes (Avetisyan, 2017, Yermakova, 2009).

\section{Results and discussions}

In the recent decade, intensive forest exploitation has considerably deteriorated the ecological balance of forest geo-system, and the most vital forest property - forest self-renewal ability - has also been disturbed.
The main goal of forest rehabilitation is the recovery of forest ecosystems by means of various strategies.

The recovery of forest-covered territories and disturbed ecosystems is particularly important for the biodiversity conservation, as well as for the improvement of forest quality and microclimatic conditions, which in their turn can ensure the sustainability of forest geo-systems.

Throughout 2019, in the Hrazdan forest farm forest rehabilitation activities on 10 ha land area were implemented, while in 2018 the mentioned activities took place along 9.8 ha land area. That is, almost the full volume of planned forest rehabilitation activities for those years was fulfilled.

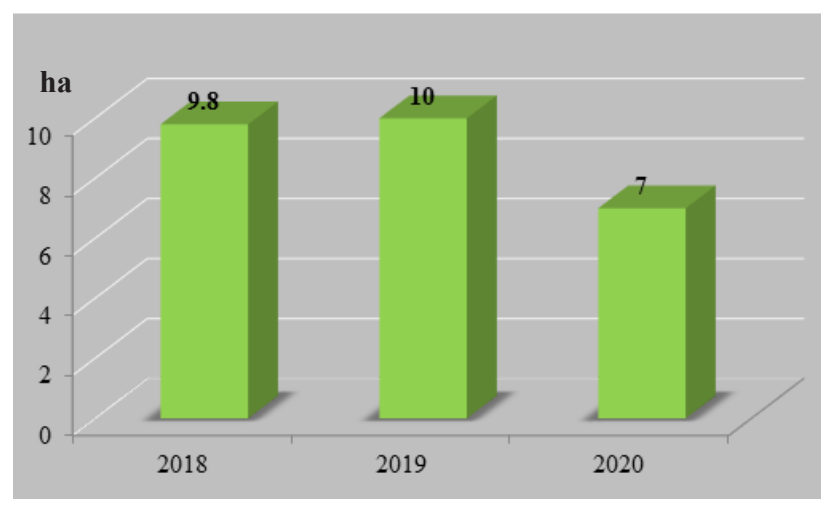

Figure 1. The volumes of forest rehabilitation activities implemented in the Hrazdan forest farm, ha ( 20182020) (composed by the authors).

It was planned that forest rehabilitation activities for 2020 should be implemented on 10 ha territory; anyhow, due to the Covid-19 broken out in spring and the Artsakh war unleashed in September, 2020, the planned activities were performed only in 7 ha land area, which makes $70 \%$ of the total planned activities. Therefore, the underperformance, due to the mentioned reasons, made $30 \%$ (Figure 1).

The branch of Hrazdan Forest Farm owns 17 ha nursery area (only 3.3 ha area is still being used). Here high quality planting materials with root-balled tree system for forest tree varieties, such as pine, birch, apple and ash trees, were grown through contemporary methods, which were later transplanted in the forest sites for forest rehabilitation and afforestation purposes. 
During the forest recovery and afforestation activities implemented in autumn, 2019, about 125 thousand high quality planting materials of different tree varieties grown through root-balled tree system were used. About 250000 planting materials with the mentioned contemporary system was grown in 2019 for their application in 2020.

In 2020, about 219 thousand saplings were produced, the majority of which was with root-balled tree system. Growing planting material with such a system is a rather efficient method, in case of which the saplings are endowed with high adaptability and survivability (99 \%) (http://kotayk.mtad.am/kotayk/).

Investigating the forest recovery process in the Hrazdan forest farm (2018-2020), it has been found out that in 2018, 2019 and 2020 the employees of forest farm organized and implemented almost $100 \%$ sanitation cutting (removal of dry and old tree branches, individual dry trees, stump shoots) in all forest districts.

Nevertheless, the situation is somehow different regarding the illegal logging recorded in the mentioned forest farm. Like in all forest farms of the republic, also in the Hrazdan forest farm, illegal logging has been recorded throughout different years.

Related to insufficient socioeconomic state of the RA population, including in Kotayk region, the illegal loggings still bear ongoing character in the forest enterprises of the republic. According to the data of State Forest Committee under the Ministry of Environment, the area of illegal loggings in the republic constitutes $35 \%$ of the territory where forest rehabilitation activities are planned and implemented.

In 2018 and 2019, the illegal loggings in the Hrazdan forest farm (including all forest districts) made 2.2 and 1.8 ha respectively (the calculation was conducted based on the number of cut and left trees per 1 hectare land area). Based on the rates of rehabilitation activities, it should be noted that the illegal loggings in 2018 could have constituted $22.45 \%$ of the recovered area, while in 2019 it could have been $18.0 \%$.

The situation is slightly different for 2020, when the illegal loggings in the forest farm was recorded on 3.95 ha land area (2000 trees and shrubs per hectare are registered according to the data of forest farm, which constitutes $56.4 \%$ of the recovered tree nurseries in that year). This is due to the outbreak of the pandemic Covid-19 and the 44-day Artsakh war resulting in post-war socioeconomic crisis, which the great part of the RA population experienced. In this period, the socioeconomic situation of the population was exacerbated: means of sustenance, employability and fuel shortage became pressing issues.

Armenia is a unique country with its distinguished nature and clean air. Both the tourists and local people mark out several places which best comply with eco-tourism requirements. For example, all year round zipline and armchair- ropeway is operating in the Tsaghkadzor city located on the eastern slope of Mount Teghanis at an altitude of 1966-2819 m high above sea level, which is the center of tourism and downhill skiing.

According to the data provided by the Tsaghkadzor ropeway directorate, the number of visitors in winter months made 1000-1500 people per day, while in spring it made $600-800$ people/day. According to the available data the overwhelming part of visitors were foreigners from Russian Federation and Islamic Republic of Iran.

These indices relate to 2018-2019 years, while in 2020 they got reduced, since the pandemic and war had a rather adverse effect on the economic and social state of both Armenian population and those of the neighboring countries. The number of visitors was mostly reduced in spring, 2020, since due to Covid-19 all air and land routes providing exit and entry to the RA, were closed.

Table. Estimation of demographic capacity in the Tsaghkadzor forest district*

\begin{tabular}{|c|c|c|c|c|c|c|c|c|c|c|}
$\begin{array}{c}\text { Tsaghkadzor } \\
\text { forest } \\
\text { district }\end{array}$ & $\boldsymbol{S}$ & $\boldsymbol{A}$ & $\boldsymbol{S}_{\boldsymbol{g}}$ & $\boldsymbol{K}_{\boldsymbol{I}}$ & $\boldsymbol{K}_{\mathbf{2}}$ & $\boldsymbol{K}_{\mathbf{3}}$ & $\boldsymbol{M}_{\boldsymbol{1}}$ & $\boldsymbol{H}$ & $\boldsymbol{D}_{\mathbf{1}}$ \\
\hline
\end{tabular}

*Composed by the authors. 
In summer, Armenia restarted to accept visitors observing all epidemic-prevention rules, anyhow, at the end of September the Artskh war broke out, which again entailed to the reduction of visitors by about $36 \%$. As a result, many workplaces in the tourist companies were reduced and consequently more than 132 people were dismissed.

In the current research work demographic capacity of the Tsaghkadzor forest district per the recreation resources has been calculated. In order to determine the maximum value of permissible burden in the recreation area the following formula has been used (Yermakova, 2009):

$$
D_{1}=\frac{\left(S \cdot A+S_{g}\right) \cdot K_{1} \cdot 10}{H \cdot M_{1}} \cdot K_{2} \cdot K_{3},
$$

where $D_{1}$ is the demographic capacity according to the opportunity of organizing recreation in forest and riverine areas, $S$ is the total area $\left(\mathrm{km}^{2}\right), A$ is the forestcover (in \%), $S_{\mathrm{g}}$ is the area occupied with water objects $\left(\mathrm{km}^{2}\right), K_{1}$ is the coefficient of recreation organized in green zones (0.5-10), $K_{2}$ is the coefficient of availability of medical-recreational resources (1.05-12), $K_{3}$ is the coefficient of availability of touristic resources $(1.05-1.2), \mathrm{H}$ is a certain recreation area $\left(2 \mathrm{~km}^{2}\right.$ area for 1000 native inhabitants), $M_{1}$ is the coefficient of allocating the leisure travelers throughout the forest areas and on the coasts of water areas (0.1- in case of warm climate and 0.3 - in case of temperate climate).

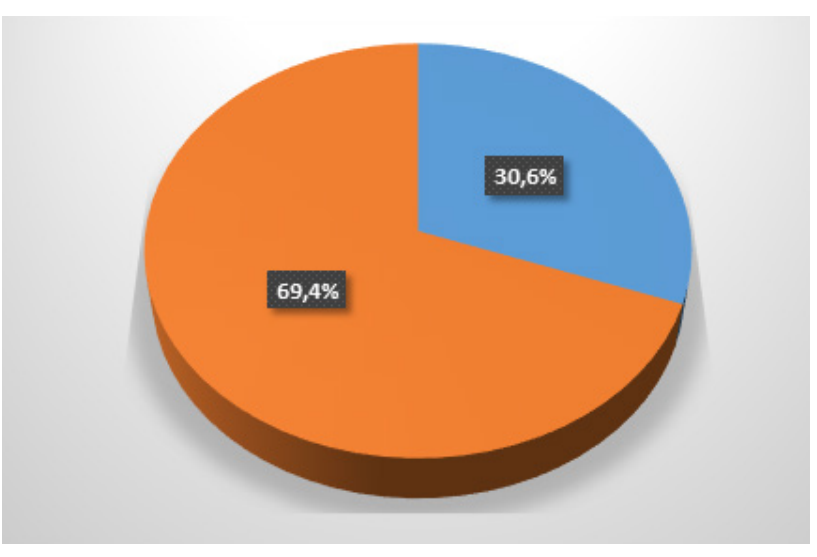

Figure 2. The index of visitors having received eco-touristic services in the Tsaghkadzor forest district against the demographic capacity of the mentioned area (data of 2020 expressed in \%) (composed by the authors).
The results of conducted calculations are presented in the table. Per our estimations the annual demographic capacity of the Tsaghkadzor forest district is equal to 70290 people.

In order to estimate the cost of eco-touristic services in the Tsaghkadzor forest district the number of the visitors recorded for a year has been multiplied by the entrance fee (500 AMD per capita) set.

In 2018 the number of visitors made 47400 people, while in 2019 it accounted for 51760 people. That is, in 2018 the cost of eco-touristic services was equal to $23 \mathrm{mln} 700$ thousand AMD, while in 2019 it equaled to $25 \mathrm{mln} 880$ thousand AMD.

In 2020, related to the pandemic of coronavirus broken out in spring and then 44-day war, started on September 27 , the number of visitors sharply fell down making all in all 21550 people. Hence, the cost of eco-touristic services was estimated as $10 \mathrm{mln} 775$ thousand AMD. Whereas the demographic capacity of the mentioned area makes $35 \mathrm{mln} 145$ thousand AMD, therefore, out of the total $35 \mathrm{mln} 145$ thousand AMD recreation and eco-touristic services available in the Tsaghkadzor city only those estimated as $10 \mathrm{mln} 755$ thousand AMD (30.6\% of the total) were rendered in 2020 (Figure 2).

\section{Conclusion}

Summing up the research results obtained about the forest eco-touristic services and forest rehabilitation activities by the example of Hrazdan forest farm the following statements can be inferred:

1. In 2018, the forest rehabilitation activities in the Hrazdan forest farm were implemented throughout 10 ha land area and in 2019 they were accomplished along 9.8 ha land area. In 2020 it was planned to implement forest rehabilitation activities again on 10 ha area, anyhow, due to the pandemic of Covid-19 broken out in spring and then the September war, the mentioned activities were conducted only on 7 ha land area, i.e., the underperformance of planned rehabilitation activities made $30 \%$.

2. In the period of investigations conducted in the forest farm the illegal loggings amounted to considerable quantities (\%), which in 2020, again related to the pandemic and war made 3.95 ha or $56.4 \%$ against the 
recovered territory, while in the previous years (2018, 2019) the illegal loggings accounted for 2.2 and 1.8 ha respectively.

3. In 2018 the cost of eco-touristic services in the Tsaghkadzor forest district made $23 \mathrm{mln} 700$ thousand AMD, while in 2019 it was estimated as $25 \mathrm{mln} 880$ thousand AMD. Out of the total recreation and ecotouristic services estimated about $35 \mathrm{mln} 145$ thousand AMD only those with the amount of $10 \mathrm{mln} 755$ thousand AMD (30.6\% of the total) were rendered in 2020 .

\section{References}

1. Atlas of Soils of the RA. Yerevan, Scientific Research Centre of Soil Science and Agrochemistry, 1990, - 65 p. (in Russian).

2. Avetisyan, G. (2017). Integration of Forest Ecosystem Services in Forest Management Plans. Proceedings of Scientific Articles. The Current Issues of Economic Development and Allocation in the Republic of Armenia and Neighboring Foreign Countries. "Meknark" Publishing House, Yerevan, - pp. 147-153 (in Armenian).
3. Concept of Creating Innovative Financial and Economic Mechanisms in the Field of Nature Protection - Yerevan, 2013, - 17 p. (in Armenian).

4. Galstyan, M.H., Mkrtchyan, A.L. (2013). Natural Resources of the RA. Teaching Manual for the Laboratory and Practical Classes on the Subject of "Agriecology and Environmental Protection", Yerevan, ANAU, - 192 p. (+32 p. supplement).

5. Gevorgyan, A. (2014). Scoping Study of Economic Significance of Ecosystems and Biodiversity (TEEB) of the Forestry Sector of Armenia, Yerevan, - 53 p. https://ace.aua.am/files/2019/05/scoping study of economic significance.pdf (accessed on 10.04.2020).

6. Global Carbon Project Report- Earth Syst. Sci. Data, 7, 2015,- pp. 47-85.

7. http://forestcommittee.am (accessed on 13.11.2020).

8. http://kotayk.mtad.am/kotayk/(accessed on 15.02.2021).

9. http://www.mnp.am/ (accessed on 20.01.2021).

10. Yermakova, A.A. (2009). Problems of Definition of Recreational Pressure and Recreational Capacity of Territories // Bulletin of the Voronezh State University, - pp. 16-20. 